\title{
IMPACT OF CONVENTIONAL STOCK MARKET INDEX ON ISLAMIC STOCK MARKET INDEX IN BOSNIA AND HERZEGOVINA
}

\section{Edin Djedović ${ }^{1}$ Irfan Djedović}

Original scientific paper

Cantonal Administration for Inspection Affairs of Tuzla Canton, Tuzla, Bosnia and Herezegovina

Received: 2018/11/14

Accepted: 2019/2/10

\begin{abstract}
This study analyzes the impact of conventional index (SASX-30) on Islamic index (SASE-BBI) in Bosnia and Herzegovina. In the study are used daily index observations spanning in a period from October 2016 until May 2018. The data is obtained from the Sarajevo Stock Exchange database. Vector Auto-regression analysis (VAR) and Impulse response functions are used in order to estimate the impact. The results show that there is a significant negative impact of conventional index volatility (SASX-30) on Islamic index volatility (SASX-BBI) in Bosnia and Herzegovina.
\end{abstract}

Keywords: conventional stock market index, Islamic stock market index, impact, $B \& H$

\section{INTRODUCTION}

Islamic financial services around the world are witnessing rapid growth in the recent decades. There is significant increase in the demand for Islamic financial instruments. More precisely, there is significant increase in the demand for investing in Islamically acceptable stock market indices. These indices are based on the Shariah law, and therefore they are acceptable from the Islamic perspective.

There are few worldwide accepted methodologies for creating Islamic stock market index. These methodologies include FTSE global Islamic market index Shariah rules, MSCI Global Islamic market index Shariah rules etc.. These screening methodologies usually include two types of filters including business screening and financial screening. After fitting both of the screening criteria a stock can enter the list of companies listed in the Islamic stock market index. Furthermore, these aspects of companies listed in the index are checked periodically over time to see whether a company fits the criteria over time.

„Al-Khazali, Lean and Samet (2013) highlight that the investment in companies that are compliant with Islamic laws is consistent with socially responsible and ethical investment, in which investors select their stocks based on their religious beliefs“". (Djedovic \& Ergun, 2018).

In the last few decades, the international Islamic financial market has gathered a significant momentum in attracting capital from both Muslim and nonMuslim countries and investors. There are few favored global Islamic indices such as DJIM, FTSE, MSCI etc. Furthermore, the development of Islamic capital markets, in both domestic and global markets, is showing positive trends over time.

\footnotetext{
${ }^{\mathbf{1} C o r r e s p o n d e n c e}$ to:

Edin Djedović, Cantonal Administration for Inspection Affairs of Tuzla Canton, Bosnia and Herezegovina

$\mathrm{PhD}$ in Economics (Management) at the International Burch University

Phone: +38761731 129

E-mail: e_djedovich@hotmail.com
} 
Sarajevo Stock Exchange introduced first Islamic index (SASX-BBI) in Bosnia and Herzegovina in October 2016. The index is introduced in cooperation with Bosna Bank International.

According to Dharani and Natarajan (2011), Islamic Index comprises Shari'ah compliant stocks which provide essential advantages of being socially responsible and ethically sound. Hassan and Girard (2011) referred to the McKinsey Management Consulting Firm report and concluded that Islamic finance is a new force in the financial market place as this niche market is attracting potential investors.

Therefore, the research that investigates Islamic indices' behavior is of a great significance nowadays, due to its higher importance and popularity, as well as the need for a deeper investigation of this financial sector, since the literature covering these issues is still developing.

This type of research could be beneficial for the academic society as well as for the investors.

This study examines the impact of conventional stock market index (SASX-30) on Islamic stock market index (SASX-BBI) return and volatility in Bosnia and Herzegovina. Study investigates one of the potential factors that affects Islamic stock market index (SASX-BBI) return and volatility. The factor being mentioned is the return and volatility rate of the conventional counterpart index.

Despite the fact that the academic research on the relationship between conventional stock market indices is widely analyzed, there is a certain gap in the literature pertaining to the relationship between conventional and Islamic stock market indices. Furthermore, this is the first research of this type in Bosnia and Herzegovina.

Based on some of the previous research investigating conventional as well as Islamic stock market indices, there are evidences that conventional and Islamic stock market indices are similarly influenced, and that conventional indices impact the movement of Islamic ones.

However, some of the studies find that these indices are independently moving.

Since the literature investigating the behavior of the Islamic stock market indices is still developing, it is important to investigate if there is an impact on the Islamic stock market index return and volatility in Bosnia and Herzegovina, coming from the conventional counterpart index.

The results from this study suggest that volatility of conventional SASX-30 index has significant nega- tive impact on the volatility of the Islamic index, SASXBBI, in Bosnia and Herzegovina.

\section{LITERATURE REVIEW}

Studies investigating relationship and potential impact of conventional indices on Islamic ones, and viceversa, are still developing. Based on some of the fundamental differences between Islamic and conventional stock market indices, it might be expected that there should not be potential transmission of risk or volatility across Islamic and conventional indices.

Albaity and Ahmad (2008) examined the relationship between the Kuala Lumpur Shariah Index (KLSI) and the Kuala Lumpur Composite Index (KLCI) during the period 1999-2005. They found that the short-run causality is bi-directional between the two indices.

Bakri Abdul et al. (2014) found significant short-run bidirectional causality between Malaysian Islamic stock market and conventional stock market.

Majdoub and Mansour (2014) find weak correlation between US and five Islamic emerging equity markets over time.

Nazlioglu et al. (2015) examined whether there is volatility transmission between the Dow Jones Islamic stock index and the three conventional stock markets for the U.S., Europe and Asia. They found that there is volatility spillover between Islamic and conventional indices. Furthermore, Kim and Sohn (2016) in their study found unidirectional volatility spillover from the U.S. conventional stock market to the Islamic stock indices of Islamic countries, but not vice versa. The Islamic stock index is also influenced by the U.S. conventional stock index (Dow Jones Industrial Average - DJIA).

Bahloul, Mroua and Naifar (2017) examined the impact of the conventional index return and volatility on Islamic stock market return for the period 2002 to 2014 (monthly data). They included ten developed and ten emerging markets. The results suggest that the conventional index return has significant impact on Islamic index return.

Furthermore, Djedovic and Ergun (2018) investigated eventual volatility spillover between conventional and Islamic index in the UK. Their results suggest that there is significant positive impact of Dow Jones UK index volatility on Dow Jones UK Islamic index volatility.

To summarize, empirical literature on the issue of volatility transmission between Islamic and conventional equities generaly shows that there is relationship and volatility spillover between conventional and Islamic indices. 


\section{DATA AND METHODOLOGY}

In this study used are daily observations of conventional and Islamic stock market index in Bosnia and Herzegovina. The data spans from the October 2016 to May 2018. We obtained the data from the Sarajevo Stock Exchange database. Vector Auto-regression analysis and Impulse response functions are used in order to estimate the impact.

The arithmetic return of the indices is estimated by subtracting the index value at time $\mathrm{t}-1$ from the index value at time $t$ and dividing it by the index value at time $t$ as shown in Eq. (1), where Rt is the return at time $\mathrm{t}, \mathrm{Pt}$ is the index at time $\mathrm{t}$, and Pt-1 is the index at time $\mathrm{t}-1$.

Equation 1. $\quad \mathrm{Rt}=(\mathrm{Pt}-\mathrm{Pt}-1) / \mathrm{Pt}-1$

The next step is the estimation of the volatility of the indices. Volatility is measured as square of the deviations from the mean. We consider that $\Delta \boldsymbol{y}_{\boldsymbol{t}}$ indicates the series with deviations from means.

As it can be seen in the Equation 2., the volatility of the indices is estimated as:

Equation 2. $\Delta y_{t}^{2}=\left(\Delta y_{t}-\Delta \bar{y}\right)^{2}$

where $\Delta \bar{y}=\Sigma \Delta y_{t} / T$.

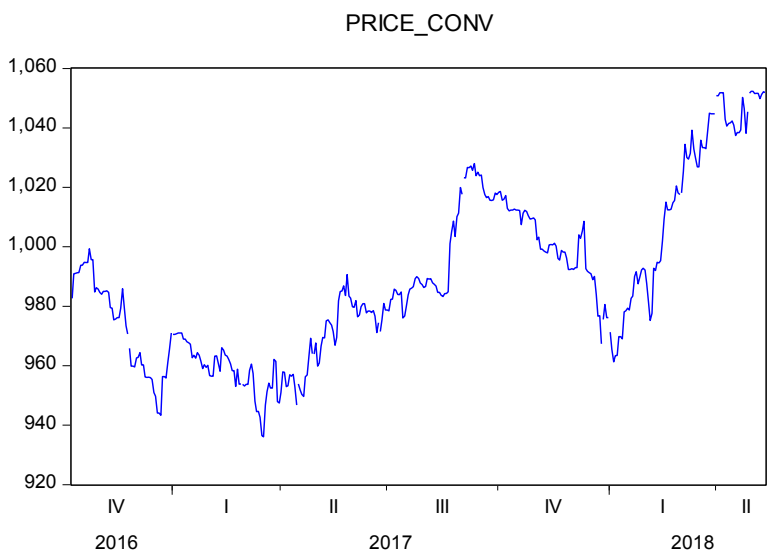

Figure 1

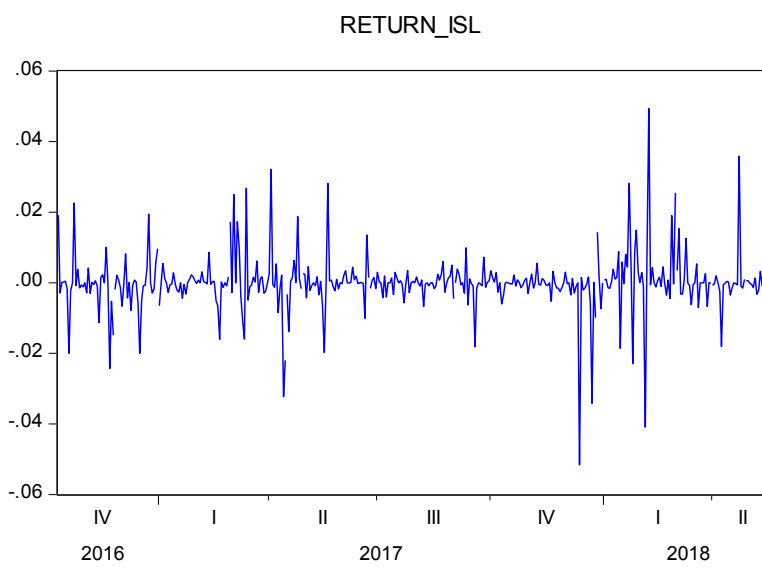

Figure 3

\section{EMPIRICAL ANALYSIS AND RESULTS}

In this part of paper presented are graphs representing the movement of the two indices (price, return and volatility) over time, the unit root tests for the time series used in the analysis part, as well as the results of the VAR analysis and impulse response functions.

\section{Graphical representation}

In this section presented are prices, return and volatility values of conventional (SASX-30) and Islamic (SASX-BBI) indices in Bosnia and Herzegovina for the observed time period.

In the Figures 1 and 2 presented are the prices of the indices for the observed period. In the Figures 3 and 4 presented are the return values of the indices. Furthermore, in the Figure 5 and 6 presented are volatility values of the two indices for the observed period.

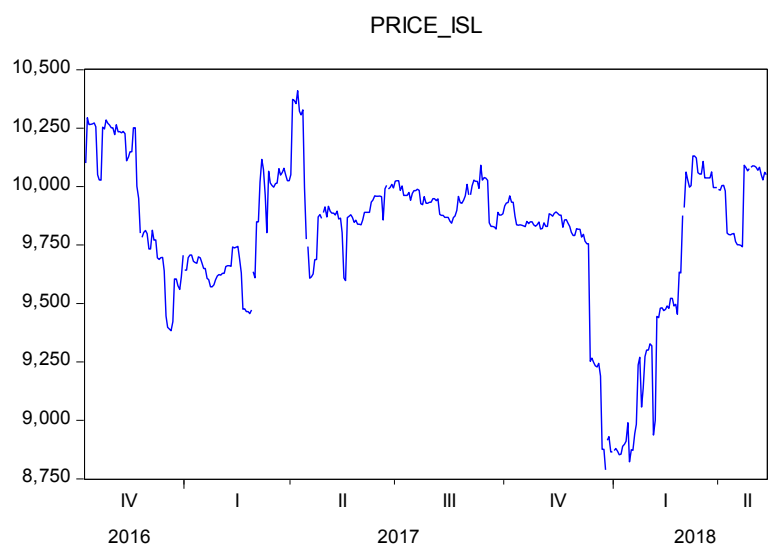

Figure 2

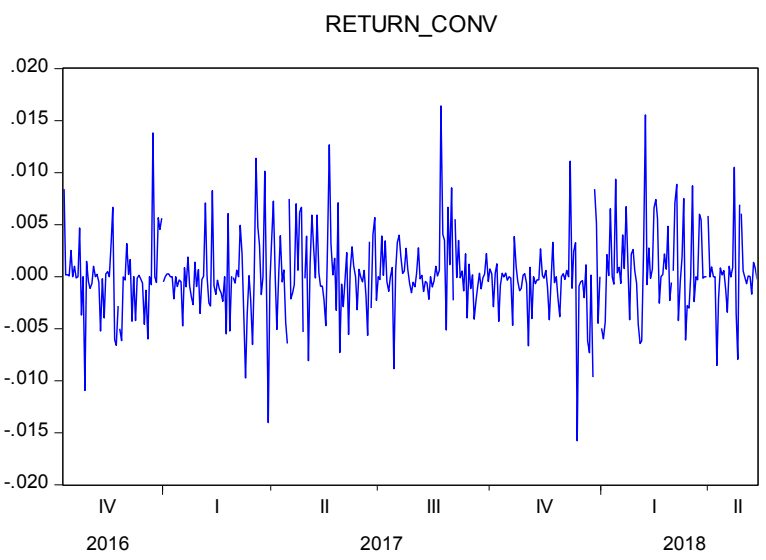

Figure 4 


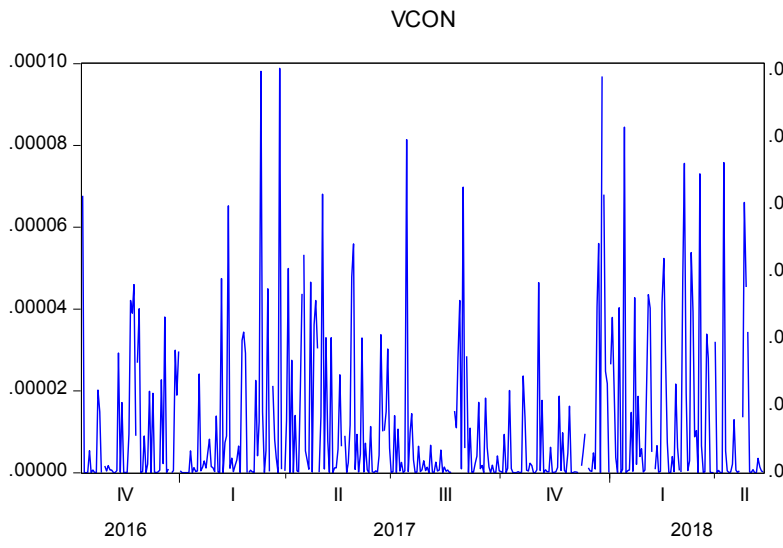

Figure 5
VISL

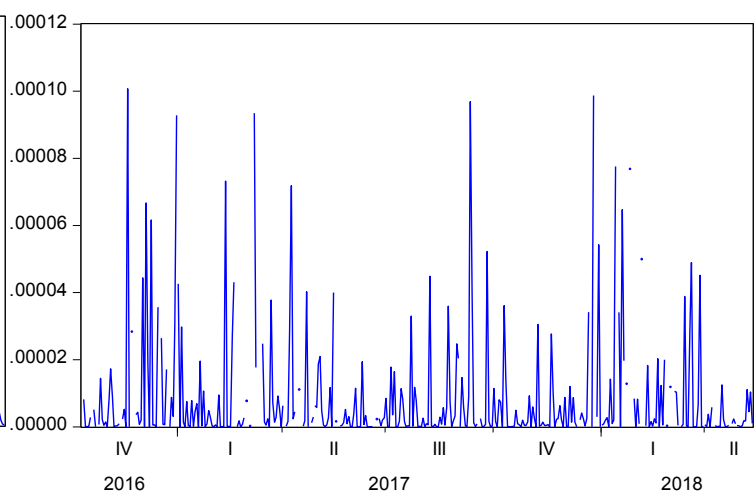

Figure 6

\section{Unit root test}

In this section presented are the ADF unit root tests for the variables used in the study. The results given in Table 1., Table 2., Table 3. and Table 4. suggest that the variables used in the study are stationary at the levels.

Table 1. ADF Unit root test for SASX-30 return

Null Hypothesis: RETURN_SASX_30 has a unit root

Exogenous: Constant

Lag Length: 0 (Automatic - based on SIC, maxlag=16)

\begin{tabular}{llll}
\hline & & t-Statistic & Prob. ${ }^{*}$ \\
\hline Augmented Dickey-Fuller test statistic & & -19.00880 & $\mathbf{0 . 0 0 0 0}$ \\
\hline Test critical values: & $1 \%$ level & -3.446608 \\
& $5 \%$ level & -2.868601 \\
& $10 \%$ level & -2.570597 \\
\hline
\end{tabular}

*MacKinnon (1996) one-sided p-values.

Table 2. ADF Unit root test for SASX-BBI return

Null Hypothesis: RETURN_ISL has a unit root

Exogenous: Constant

Lag Length: 0 (Automatic - based on SIC, maxlag=16)

\begin{tabular}{llll}
\hline & & t-Statistic & Prob. ${ }^{*}$ \\
\hline Augmented Dickey-Fuller test statistic & & -19.37085 & $\mathbf{0 . 0 0 0 0}$ \\
\hline Test critical values: & $1 \%$ level & -3.446608 \\
& $5 \%$ level & -2.868601 \\
& $10 \%$ level & -2.570597 \\
\hline
\end{tabular}

*MacKinnon (1996) one-sided p-values.

Table 3. ADF Unit root test for SASX-30 volatility

Null Hypothesis: VCON has a unit root

Exogenous: Constant

Lag Length: 0 (Automatic - based on SIC, maxlag=16)

\begin{tabular}{|c|c|c|c|}
\hline & & t-Statistic & Prob.* \\
\hline \multicolumn{2}{|c|}{ Augmented Dickey-Fuller test statistic } & -20.48159 & 0.0000 \\
\hline \multirow[t]{3}{*}{ Test critical values: } & $1 \%$ level & -3.446608 & \\
\hline & $5 \%$ level & -2.868601 & \\
\hline & $10 \%$ level & -2.570597 & \\
\hline
\end{tabular}

*MacKinnon (1996) one-sided p-values. 
Table 4. ADF Unit root test for $S A S X-B B I$ volatility

Null Hypothesis: VISL has a unit root

Exogenous: Constant

Lag Length: 1 (Automatic - based on SIC, maxlag=16)

\begin{tabular}{|c|c|c|c|}
\hline & & t-Statistic & Prob.* \\
\hline \multicolumn{2}{|c|}{ Augmented Dickey-Fuller test statistic } & -11.70661 & 0.0000 \\
\hline \multirow[t]{3}{*}{ Test critical values: } & $1 \%$ level & -3.446650 & \\
\hline & $5 \%$ level & -2.868620 & \\
\hline & $10 \%$ level & -2.570607 & \\
\hline
\end{tabular}

\section{Vector Autoregression Analysis (VAR)}

Vector autoregression (VAR) is a model used to find the linear interdependencies among time series. A VAR has more than one dependent variable and has more than one equation. VAR analysis enables us to estimate the predictive power of the variables. By using VAR framework, we carry out the analysis to assess the predictive power of the conventional index in Bosnia and Herzegovina in explaining the Islamic index behavior. Vector Autoregressive Analysis (VAR) requires that the data is stationary in order to avoid spurious regression.

Table 5. Vector autoregression analysis (VAR)

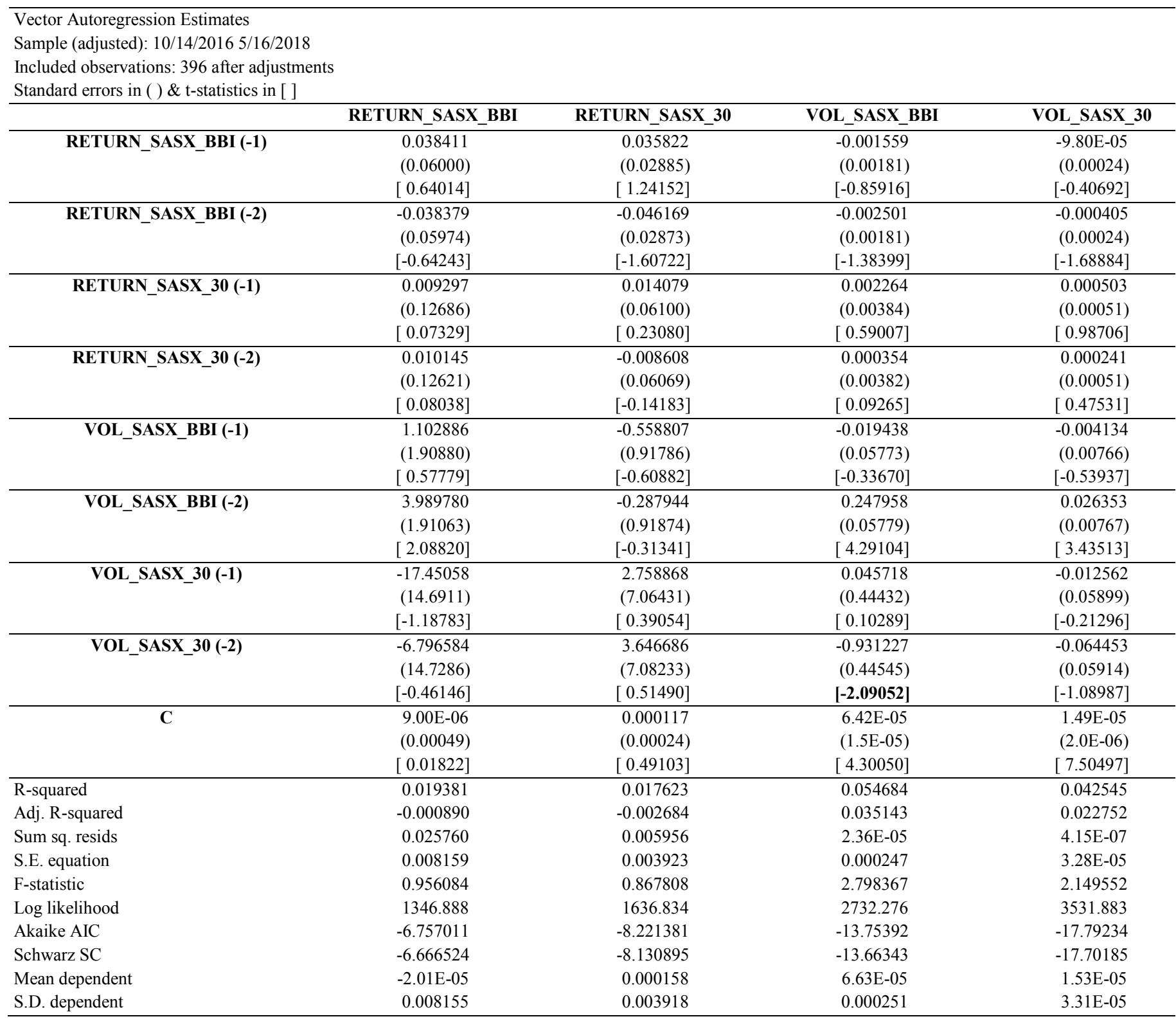


The empirical results obtained through Vector Autoregressive method are summarized in the Table 5. The results from the Table 5. indicate that the volatility of the conventional index (SASX-30) has a negative significant impact on the volatility of Islamic index (SASX-BBI). This impact comes after two periods (lag -2). This suggests that the higher volatility of the conventional index, the volatility of Islamic index in Bosnia and Herzegovina will be lower after two periods. This suggests that when there is higher amount of risk in conventional index, Islamic index will be less risky after two periods.

The other results from the Vector autoregression analysis suggest that conventional index return has no significant impact on Islamic index return, meaning that Islamic index return is independent from conventional index return in Bosnia and Herzegovina. Furthermore, conventional index return has no significant impact on Islamic index volatility. Also, from the results it can be noticed that the volatility of conventional index in Bosnia and Herzegovina has no significant impact on Islamic index return.

By summarizing the results of VAR analysis, it only conventional index volatility in Bosnia and Herzegovina has negative significant impact on Islamic index volatility. The other results are not significant.

\section{Impulse Response Functions (IRFs) Results}

In order to test how the Islamic index in Bosnia and
Herzegovina responds to the short-run temporary shocks in the counterpart conventional index, this study employs the impulse response function. The impulse response function is derived from the estimation of the VAR model and are presented in Figures 7 to 10.

As Mohsen et al. (2017) state ,impulse response functions (IRFs) are used to study the dynamic effects of a particular variable's shock on the other variables that are included in the same model. Through the IRF we can learn whether the response of one variable to changes in the other variables is positive (the point estimate is above zero) or negative (point estimate is under zero) and whether it is significant or not. If the point estimate of the IRF passes through the zero line, the response is insignificant". In this study we use Cholesky decomposition adjusted response functions.

Figure 7 shows that SASX-BBI index return responds negatively to a shock in SASX-30 return after the third period, and the impact of the shock comes to its peak in the fifth period. After the fifth period, the impact starts to fade away and becomes zero at the end of sixth period. This means that there is a negative effect of a shock of SASX-30 index return on SASX-BBI index return. This result indicates that Islamic index in Bosnia and Herzegovina is not immune to the shocks in the conventional index, and that the higher return of the conventional index causes a decrease in the return of the Islamic index.

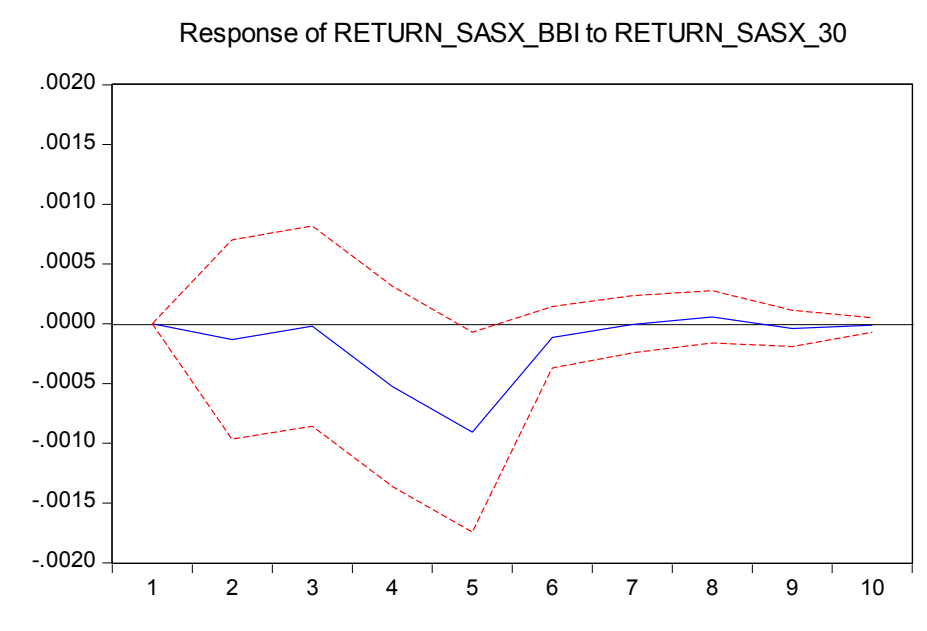

Figure 7.

As it can be seen in the Figure 8 the return of SASX-BBI index is effected by the shock in volatility of SASX-30 index. It responds negatively to a shock in the first, second and third period. After that, in the fourth and the fifth period the response is positive. After the fifth period the impacts fades away. This result indicates that the return of Islamic index is not immune to the shocks in the conventional index volatility in Bosnia and Herzegovina. 


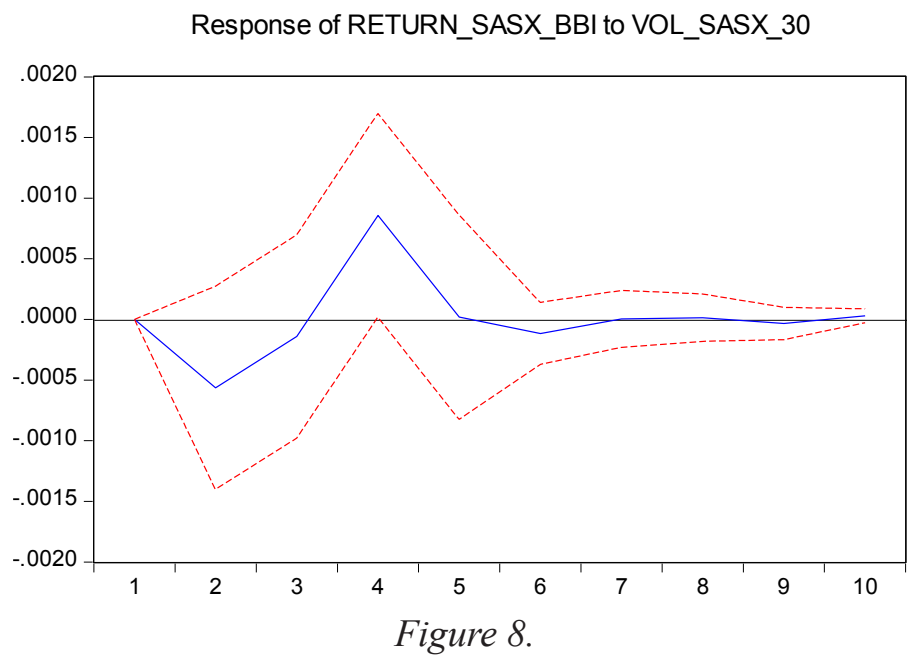

Furthermore, the result in Figure 9 shows that the lamic index return in Bosnia and Herzegovina is not volatility of SASX-BBI index responds negatively immune to the shocks coming from the counterpart to a shock in SASX-30 index return. The negative re- conventional index return. Meaning, that when the response starts during the third period and fades away turn of the conventional index is higher the volatility during the fifth period. The result suggests that Is- of Islamic index in Bosnia and Herzegovina is lower.

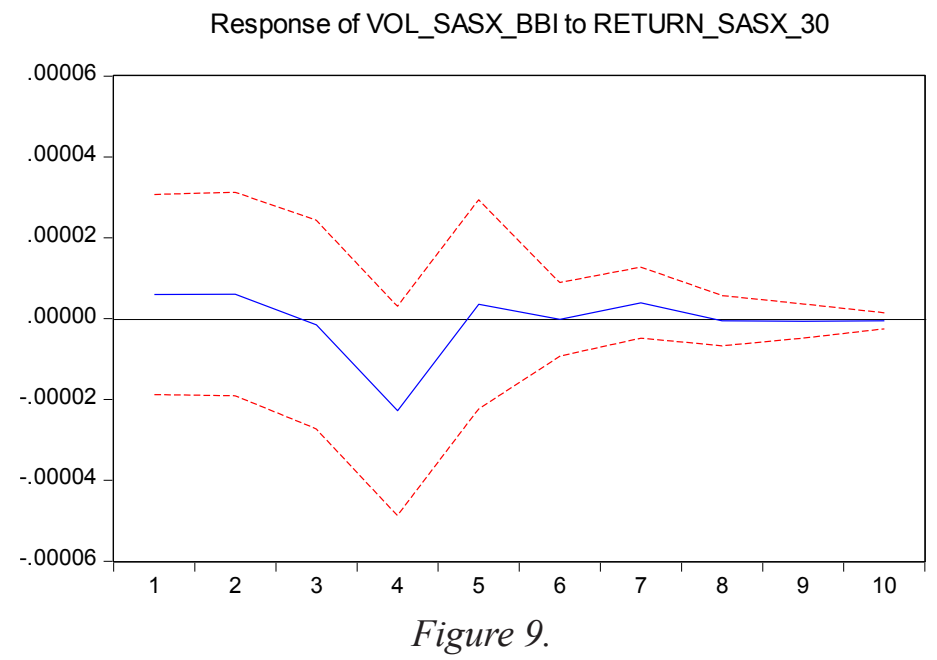

Figure 10 shows that SASX-BBI index volatility ing the sixth period the response fades away and beresponds negatively to a SASX-30 volatility during comes zero. The results from Figure 4 suggest that the third period. After that, the response of SASX- Islamic index volatility in Bosnia and Herzegovina BBI volatility to the shocks in SASX-30 volatility is not immune to the conventional index volatility is positive, during the fourth and fifth period. Dur- changes.

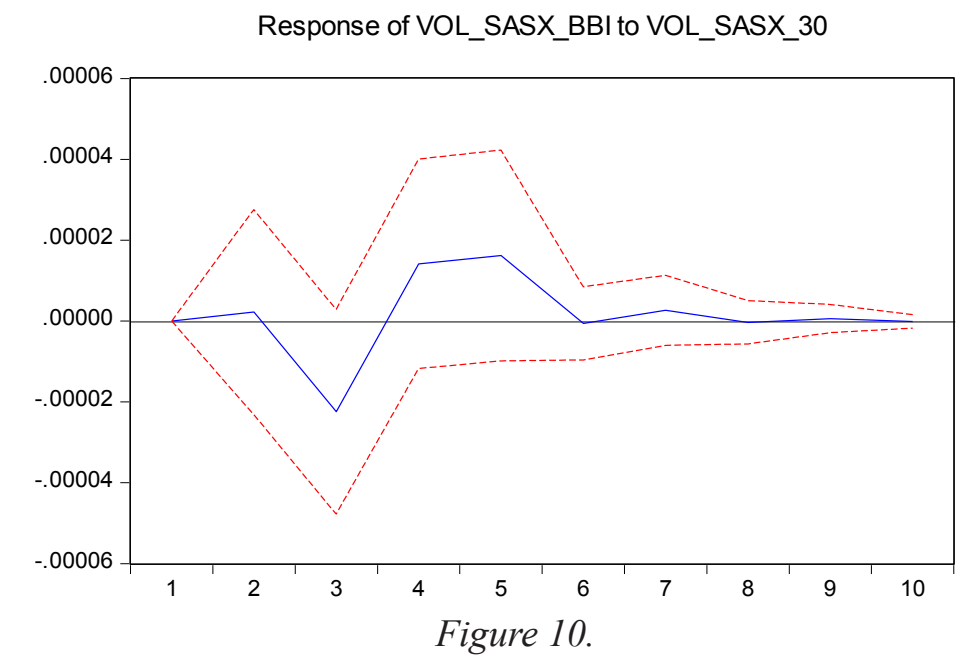


SIGNIFICANCE AND CONTRIBUTION OF THE STUDY

This is, to our best knowledge, first and pioneer empirical study regarding Islamic stock market index in Bosnia and Herzegovina. So, we can state that the study partially fills the gap regarding this topic in Bosnia and Herzegovina. However, more studies of this type should be performed in the future. Furthermore, this study contributes to the existing international literature regarding Islamic index behavior, and the impact of conventional indices on Islamic ones. Also, this study provides valuable information to the potential investors, who can better understand the relationship between conventional and Islamic index, and their eventual connections and interdependency.

\section{LIMITATION AND FUTURE STUDIES REC- OMMENDATION}

The main limitation of the study is the shortness of the time series used in the study. The main reason for this limitation is that Islamic index in Bosnia and Herzegovina is introduced in the October 2016. Therefore, relatively short period of indices movement could be observed. So, in the future, the new studies would have possibility to observe longer period of indices movement, and it can strengthen the reliability of the results. Furthemore, the studies can also observe eventual impact of Islamic index in Bosnia and Herzegovina on the conventional counterpart index.

\section{CONCLUSION}

The aim of this research was to investigate eventual impact of conventional stock market index (SASX_30) return and volatility on Islamic stock market index (SASX_BBI) return and volatility in Bosnia and Herzegovina. In order to examine the impact, conducted are the Vector autoregressive analysis (VAR) and the generalized impulse-response functions.

The results of the VAR analysis indicated a significant negative impact of the volatility of conventional index in Bosnia and Herzegovina on the volatility of Islamic index in Bosnia and Herzegovina, meaning that there is volatility spillover between conventional and Islamic index. This result suggests that when there is higher volatility of conventional index, Islamic index will be less volatile after two periods. Meaning that when conventional index is riskier, Islamic index is less risky after two periods.
However, the analysis showed that there is no significant impact of conventional index return and conventional index volatility on the Islamic index return. Also, the analysis showed that there is no significant impact of conventional index return on Islamic index volatility. These results suggest that Islamic index is immune to these type of changes in conventional index.

In order to examine the responsiveness of the transmission mechanisms of the two indices short-run temporary shocks, the generalized volatility impulse response functions were derived. The results indicated that Islamic index return and volatility are not immune to the shocks in conventional index return and volatility. There was a volatility transmission from the conventional index in Bosnia and Herzegovina to the Islamic index in Bosnia and Herzegovina. Furthermore, the shocks in the conventional index return are transmitted to the Islamic index return and volatility. Our results are in line with the most of the existing literature and research, which also finds relationship between conventional and Islamic indices (Albaity and Ahmad (2008), Bakri Abdul et al. (2014), Majdoub and Mansour (2014), Nazlioglu et al. (2015), Kim and Sohn (2016), Bahloul, Mroua and Naifar (2017), Djedovic and Ergun (2018)).

Based on the results of the study we can state that Islamic index in Bosnia and Herzegovina can be good option for the investors when there is higher volatility/ risk in the conventional index, because when the volatility of the conventional index increases, the volatility of the Islamic index would decrease. So, it can be considered as a diversification tool for the investors. Therefore, the Islamic equity investments in Bosnia and Herzegovina could constitute a viable alternative for risk-averse investors who wished to hedge their investments against the turmoil of the conventional stock market in Bosnia and Herzegovina.

For the other results regarding the first part of analysis, we stated that Islamic index return is moving independently from the conventional index return and volatility, meaning that it is immune to these changes. This might be atributted to the effect of Shariah principles which makes Islamic stock indices different compared to the conventional ones.

However, when we look at the results of the second part of analysis, it can be stated that Islamic index return and volatility is not immune to the short-run temporary shocks in the conventional index return and volatility. In this sense, it can be stated that there is certain short-run temporary dependency of the Islamic index to the conventional index. 
This information regarding short-run temporary shocks is also valuable for the investors.

The explanation for this could be found in the following argument. As Djedovic and Ergun (2018) mention, ,in a market economy, the value of a firm can be influenced both directly and indirectly. Also, Islamic scholars have made some concessions on the permissible degree of financial leverage and the level of interest income in relation to Islamic indices constituent firms. Thus, Islamic indices could be expected to be sensitive to conventional stock index changes".

\section{REFERENCES}

Albaity, M., \& Ahmad, R. (2008). Performance of Syariah and Composite Indices : Evidence from Bursa Malaysia. Asian Academy of Management Journal of Accounting and Finance, 4(1), 23-43.

Al-Khazali, O., Lean, H. H. \& Samet, A. (2013). Do Islamic stock indexes outperform conventional stock indexes? A stochastic dominance approach. Pacific-Basin Finance Journal, 28, 29-46.

Bahloul, S., Mroua, M., \& Naifar, N. (2017). The impact of macroeconomic and conventional stock market variables on Islamic index returns under regime switching. Borsa Istanbul Review, 17(1), 62-74.

Bakri Abdul, K., Ernaflovia, D., \& Muhd Hafiz Mohd, S. (2014). Islamic stock market versus conventional stock market. International Journal of Economics, Commerce and Management, 2(11).
Dharani, M. \& Natarajan, P. (2011). Equanimity of risk and return relationship between Shariah index and general index in India.

Djedovic, I. \& Ergun, U. (2018). Modelling volatility spillover between conventional and Islamic stock index in the United Kingdom. Journal of Management, Economics, and Industrial Organization, Vol.2 No.3, 2018, pp.1-17.

Hassan, K. M. \& Girard E. (2011). Faith-based ethical investing: The case of Dow Jones Islamic indexes. Working paper, Networks Financial Institute, Indiana State University.

Kim, HB. \& Sohn, T. (2016). Volatility Transmission between Conventional Finance and Islamic Finance in Stock Markets, The Macrotheme Review, 5(4).

Majdoub, J. \& Mansour, W. (2014). Islamic equity market integration and volatility spillover between emerging and US stock markets. The North American Journal of Economics and Finance, 29, 452-470.

Mohsen, A. S., Chua, S. Y., \& Che Sab, C. N. (2017). Determinants of Economic Growth in Syria between 1980 and 2010. Eurasian Journal of Business and Economics, 10(19), 81-98.

Nazlioglu, S., Hammoudeh, S., \& Gupta, R. (2015). Volatility transmission between Islamic and conventional equity markets: Evidence from causality-in-variance test. $A p$ plied Economics, 47(46), 4996-5011.

Sarajevo Stock Exchange database. 